\title{
The Assessment of Newborn Iron Stores at Birth: A Review of the Literature and Standards for Ferritin Concentrations
}

\author{
Ashajyothi M. Siddappa $^{\mathrm{a}}$ Raghavendra Rao $^{\mathrm{b}}$ Jeffrey D. Long ${ }^{\mathrm{c}}$ \\ John A. Widness ${ }^{d}$ Michael K. Georgieff ${ }^{b}$ \\ ${ }^{a}$ Division of Neonatology, Hennepin County Medical Center, and Department of Pediatrics, University of \\ Minnesota School of Medicine, ${ }^{b}$ Division of Neonatology, Department of Pediatrics, University of Minnesota \\ School of Medicine, and ' Department of Educational Psychology, College of Education and Human Development, \\ University of Minnesota, Minneapolis, Minn., ${ }^{\mathrm{d}}$ Division of Neonatology, Department of Pediatrics, University of \\ lowa School of Medicine, lowa City, lowa, USA
}

\section{Key Words}

Ferritin $\cdot$ Diabetic mother, infant $\cdot$ Iron $\cdot$ Iron deficiency

\begin{abstract}
Background: Serum ferritin measurements are used in clinical populations to estimate total body iron stores and the risk of subsequent iron deficiency or overload. The lack of normative newborn serum ferritin concentration data between 23 and 41 weeks has led to difficulty in establishing the incidence and degree of abnormal iron status in the neonatal period. Objectives: The primary objective of this review was to summarize the maternal and gestational factors that determine ferritin concentrations in full-term and preterm newborn infants and to generate comprehensive reference values. The secondary objective was to assess serum ferritin concentrations in newborn infants at risk for abnormal fetal iron metabolism, including maternal diabetes mellitus, intrauterine growth restriction and maternal smoking during pregnancy. Methods: Serum ferritin and gestational age data at birth from 457 low-risk pre-term and term infants of 23-41 weeks gestation obtained from 35 published studies reviewed from a period of 25 years and from recently collected data from our centers were assessed by regression
\end{abstract}

analysis. Slopes and intercepts of the high-risk groups were compared with the standard curve. Results: Umbilical cord serum ferritin concentrations increased with advancing gestational age, from a mean of $63 \mu \mathrm{g} / \mathrm{l}$ at 23 weeks to $171 \mu \mathrm{g} / \mathrm{l}$ at 41 weeks gestation $(p<0.001)$. The infants of diabetic mothers had a lower intercept than the control infants $(p<$ 0.001). Conclusions: Iron deficiency and overload have been implicated in neurodevelopmental impairments. Normative cord serum ferritin data may permit a more precise assessment of infants who are at risk for abnormal iron status at birth.

Copyright $\odot 2007$ S. Karger AG, Basel

\section{Background}

Iron is an essential micronutrient that plays a significant role in critical cellular functions in all organ systems in all species. Iron is particularly vital for early brain growth and function in humans since it supports neuronal and glial energy metabolism, neurotransmitter synthesis and myelination [1-5]. The need to establish standard curves for cord serum ferritin concentrations throughout the third trimester of pregnancy is based on

\section{KARGER \\ Fax +4161306 1234 E-Mail karger@karger.ch}

๑) 2007 S. Karger AG, Basel www.karger.com
Accessible online at: www.karger.com/neo
Michael K. Georgieff, MD

MMC 39, D-136 Mayo Building

420 Delaware St. SE

Minneapolis, MN 55455 (USA)

Tel. +1 612626 2971, Fax +1 612624 8176, E-Mail georg001@umn.edu 
the risk of developing brain iron deficiency as storage iron pools become depleted in certain gestational conditions [6-8]. Iron deficiency during the fetal or postnatal periods can alter brain structure, neurochemistry and cognitive functioning, and lead to long-term cognitive and motor impairment that cannot be corrected by iron supplementation [9-11]. Newborn infants with the lowest quartile of cord ferritin concentrations $(<76 \mu \mathrm{g} / \mathrm{l})$ have impaired mental and psychomotor function at school age [12]. Iron-deficient infants of diabetic mothers (IDM) with low neonatal ferritin concentrations $(<35 \mu \mathrm{g} / \mathrm{l})$ have impaired auditory recognition memory processing at birth compared with iron-sufficient IDM (ferritin $>35$ $\mu \mathrm{g} / \mathrm{l})$ [13]. Pre-term infants with low serum ferritin concentrations $(<75 \mu \mathrm{g} / \mathrm{l})$ at 37 weeks post-conception have abnormal neurologic reflexes [14].

Direct measurement of brain iron in newborn infants is not currently feasible. Total body iron and iron storage estimates are based on measurements of serum markers, such as hemoglobin (Hgb) and ferritin concentrations [15]. Measurement of fetal and neonatal iron stores as a proxy for non-heme tissue iron deficiency is based on the principle that there is a hierarchical loss of tissue iron after the iron stores are depleted $[1,6]$. Under conditions of negative iron balance, the red blood cell (RBC) iron is preserved at the expense of brain iron, which, in turn, is spared at the expense of heart and skeletal muscle iron $[1,6]$.

A wide spectrum of measures are used to diagnose iron deficiency. Hgb, mean corpuscular volume, and red cell distribution width are late markers of iron deficiency and may not reflect tissue iron status in newborn infants. Zinc protoporphyrin ( $\mathrm{ZnPP})$ and $\mathrm{ZnPP}$ to heme ratio $(\mathrm{ZnPP} / \mathrm{H})$ are elevated during iron-deficient erythropoiesis, but in neonates it is not clear whether elevated $\mathrm{ZnPP} /$ $\mathrm{H}$ ratios reflect enhanced rates of erythropoiesis during rapid growth or true total body iron deficiency [16]. Moreover, $\mathrm{ZnPP} / \mathrm{H}$ ratio is affected by maternal chorioamnionitis [17]. Elevated serum transferrin receptor (sTfR) and sTfR to log of ferritin ratio reflect tissue iron deficiency and are seen in neonates following maternal iron deficiency and smoking. The data on sTfR are relatively limited in newborn term and pre-term infants, and additional studies are needed to establish normal standards for newborn infants [15].

Serum ferritin concentration has been used as a standard measurement of iron stores in infants, children and adults [18-21]. The relationships between ferritin concentrations and total body storage iron in these populations are well established. In adults, $1 \mu \mathrm{g} / \mathrm{l}$ of serum ferritin is equivalent to $8-10 \mathrm{mg}$ of storage iron [22]. In new- born infants, the ratio of serum ferritin to liver non-heme iron concentration is closer to 1:2.7 [23]. In spite of the wide availability of serum ferritin as a screening test, normative data at birth, as a function of specific gestational ages from 23 to 41 weeks, are limited.

\section{Ferritin: Biology and Clinical Significance}

The major form of iron storage is ferritin. Tissue ferritin exists as a 24-unit polymer consisting of two subunits, the heavier $(\mathrm{H})$ acidic subunits and the lighter $(\mathrm{L})$ basic subunits. The standard serum ferritin assay only detects the L-rich ferritin, which is a small fraction of total body ferritin [24].

Low serum ferritin concentrations are seen only in iron deficiency. Elevated ferritin concentrations in the newborn can be a consequence of neonatal hemochromatosis, excessive iron administration or RBC transfusions. Serum ferritin concentrations are also elevated during periods of infection, inflammation and neoplasia. Under these conditions, serum ferritin behaves as an acute-phase reactant that can mask the diagnosis of iron deficiency [25].

\section{Maternal Iron Requirements and Fetal Endowment}

Iron requirements in women are significantly higher in the pregnant state than in the non-pregnant state. The total iron requirement of a full-term pregnancy is approximately $1,000 \mathrm{mg}$ [26]. Iron requirements for pregnant women increase significantly in the second and third trimesters, with the expansion of maternal blood volume and fetal red cell mass [26]. The fetus accumulates iron at a rate of $1.35 \mathrm{mg} / \mathrm{kg}$ of fetal weight in the third trimester, maintaining an average iron content of $75 \mathrm{mg} /$ $\mathrm{kg}$ of body weight during the last trimester [27, 28]. At term, $70-80 \%$ of fetal iron is present in RBCs as $\mathrm{Hgb}, 10 \%$ in tissues as myoglobin and cytochromes, and the remaining $10-15 \%$ stored in reticuloendothelial and parenchymal tissues as ferritin and hemosiderin [27].

The placenta serves as the regulatable conduit for maternal-fetal iron transport. The amount of iron passing through the placenta increases with gestation. Iron is transferred against a concentration gradient from the placenta to the fetus, especially during the later stages of pregnancy. The placenta can also serve as a storage organ for iron during pregnancy.

\section{Factors That Determine Neonatal Ferritin \\ Concentration}

Factors that influence neonatal ferritin concentration at birth include duration of gestation, fetal sex, maternal iron status and conditions altering maternal-fetal iron 
exchange. The influence of gestational age has been reported in a large number of studies, many of which contain small numbers of subjects or relatively large gestational age groupings (e.g., term vs. pre-term). In one of the larger studies, normal full-term newborn infants had cord serum concentrations between 100 and $260 \mu \mathrm{g} / \mathrm{l}$ [29]. At- or near-term female newborn infants have higher cord serum ferritin concentrations than male infants, potentially due to differences in sex hormones, blood volume and iron utilization [12]. When term and pre-term infants are combined, sex differences in cord serum ferritin levels are not as prominent [30].

The influence of gestational age on cord blood ferritin concentration has been assessed primarily through studies comparing pre-term with term infants. Pre-term infants have lower cord serum ferritin concentrations than term infants [19, 30-32]. The lower ferritin levels in preterm infants are accompanied by lower serum iron and total iron binding capacity, and by higher reticulocyte counts and cord sTfR levels, implying increased iron utilization for fetal erythropoiesis [32].

Few studies provide ferritin concentration data for specific gestational ages. Siimes and Siimes [29] demonstrated a median ferritin level of $45 \mu \mathrm{g} / \mathrm{l}$ at $14-16$ weeks gestation and $200 \mu \mathrm{g} / \mathrm{l}$ at 39 weeks gestation. Fetuses undergoing percutaneous umbilical blood sampling, but who were not affected by any pathologic maternalfetal conditions, had mean plasma ferritin increased from $17.7 \mu \mathrm{g} / \mathrm{l}$ at $18-20$ weeks gestation to $56.8 \mu \mathrm{g} / \mathrm{l}$ at 32-35 weeks gestation [33]. A similar trend in pre-term appropriate-for-gestational-age infants with birth weights from 600 to $2,000 \mathrm{~g}$ has been noted [34]. Jansson et al. [31] showed that serum ferritin concentration measured in pre-term infants at $24-48 \mathrm{~h}$ of age were significantly lower in infants $<34$ weeks gestation (range $26-$ $270 \mu \mathrm{g} / \mathrm{l})$, compared with infants $>34$ weeks gestation (range $20-600 \mu \mathrm{g} / \mathrm{l}$ ).

The influence of maternal iron status on cord serum ferritin concentration has been assessed in iron-sufficient and iron-deficient mothers. In pregnancies characterized by maternal iron sufficiency, a relationship between maternal iron status and cord serum ferritin concentrations has been difficult to demonstrate $[19,29,30$, $35,36]$. All iron indices are higher in the cord blood than in the mother [36], emphasizing that fetal iron stores are independent of maternal iron status [30]. These studies demonstrate that iron is accreted by the fetus against a concentration gradient and that transplacental iron transport increases in response to the rapidly growing fetus in late third trimester.

The Assessment of Newborn Iron Stores at Birth
Thirty percent of pregnant women have low serum ferritin concentrations at the end of pregnancy, despite prophylactic iron therapy [37]. Studies of maternal-fetal iron metabolism in pregnancies complicated by iron deficiency can be divided into those in which the mother is frankly anemic [38-40] and those in which she only has low ferritin concentrations [37, 41-44]. Term infants of frankly anemic mothers have low cord serum ferritin, iron and transferrin saturation at birth $[38,40]$. Anemic mothers (mean Hgb: 87.2 g/l) with increased erythropoietin levels have infants with low cord serum ferritin concentrations [39]. In addition, the cord serum erythropoietin at birth is inversely related to maternal $\mathrm{Hgb}$, suggesting more active erythropoietic effort secondary to hypoxemia in fetuses of anemic mothers.

Full-term infants born to iron-deficient, non-anemic mothers with low serum ferritin concentrations have lower cord serum ferritin concentrations compared with infants born to mothers who have normal ferritin concentrations [37, 41-43]. For example, the serum ferritin concentration of infants born to mothers with ferritin concentrations $<10 \mu \mathrm{g} / \mathrm{l}$ is $98.5 \pm 50.6 \mu \mathrm{g} / \mathrm{l}$ when compared with a value of $147.2 \pm 66.0 \mu \mathrm{g} / \mathrm{l}$ seen in infants born to mothers with normal ferritin concentrations [42].

In addition to maternal iron deficiency, impaired placental function and increased fetal iron demand in excess of placental transport capacity are significant risk factors for fetal/neonatal iron deficiency. Clinical conditions that result in these abnormalities of fetal iron metabolism include maternal hypertension resulting in placental vascular insufficiency and chronic fetal hypoxia with augmented fetal erythropoiesis [8].

Infants with intrauterine growth restriction (IUGR) are at risk for iron deficiency primarily because of impaired iron transport and chronic intrauterine hypoxia due to poor placental function. IUGR is seen in pregnancies complicated by severe maternal hypertension or preeclampsia, due to genetic disorders or severe maternal malnutrition. Serum ferritin concentrations are decreased and transferrin levels are increased in IUGR infants at birth $[8,29,34]$. In a postmortem study, Georgieff et al. [45] demonstrated infants with IUGR secondary to Potter's syndrome to have significantly reduced liver and brain iron concentrations compared with control infants.

Chronic fetal hypoxia increases fetal iron requirements for secondary erythropoiesis and is also characteristic of pregnancies complicated by maternal diabetes mellitus [46] and maternal smoking [47]. In these condi- 
tions the iron delivery to fetal organs such as liver, heart and brain are often reduced to maintain iron supply to the expanded red cell mass $[6,7,48,49]$.

IDM born to gestational, insulin-dependent and noninsulin-dependent diabetic mothers are at risk for low iron stores $[8,46,50]$. Sixty-five percent have ferritin concentrations $<60 \mu \mathrm{g} / \mathrm{l}$, with a mean value of $26 \mu \mathrm{g} / \mathrm{l}$ [8]. Fetal hyperglycemia and hyperinsulinemia during gestations complicated by maternal diabetes mellitus increases fetal metabolic rate and oxygen consumption and result in fetal hypoxemia $[51,52]$. The abnormal iron indices in IDM are due to increased fetal iron utilization for erythropoiesis $[46,50]$. The degree of iron abnormality at birth correlates with elevated fetal erythropoietin and fetal glycosylated $\mathrm{Hgb}$ concentrations [46]. RBC iron content increases proportionately with the decrease in serum ferritin concentration. The lower ferritin concentrations in IDM could also have been secondary to placental dysfunction preventing adequate transfer of maternal iron to the fetus [54].

Maternal smoking is another risk factor for fetal and neonatal iron deficiency. Healthy term infants born to iron-sufficient mothers who smoked during pregnancy have elevated fetal erythropoietin, cord Hgb, sTfR concentrations and decreased cord ferritin concentrations consistent with intrauterine hypoxemia $[47,54,55]$. Fetal hypoxemia was likely induced by elevated carboxyhemoglobin levels, decreased uteroplacental blood flow and increased placental vasoconstriction caused by nicotine and catecholamines [55]. Increased cord hematocrit values positively correlate with maternal thiocyanate levels [54]. There is a significant inverse relationship between cord serum ferritin and the hematocrit, suggesting iron stores are mobilized for Hgb synthesis [54].

\section{Iron Stores in Healthy Term and Pre-Term Infants at}

Birth: Generation of Standards from the Literature

and the Current Data Set

Although the neonatal literature is robust in ferritin studies, most suffer from small sample sizes and a lack of ferritin concentrations reported at specific gestational ages. Generating normal values for serum ferritin concentration in umbilical cord blood based on a greater number of subjects assessed at specific gestational ages would help to identify infants at risk for perinatal iron deficiency. The primary objective of the study was to determine the mean and the 5th and 95th percentile confidence limits of the relationship of ferritin to gestational age between 23 and 41 weeks. The secondary objective was to assess neonatal serum ferritin concentrations in infants at risk for fetal and neonatal iron deficiency.

\section{Analysis Based on Data from the Literature}

We assessed 35 papers $[12,14,19,20,23,29-42,44,47$, $50,54,56-67]$ describing neonatal ferritin concentrations in newborn infants identified through the PubMed search engine (http://www.ncbi.nlm.nih.gov/entrez/). Articles were included for generating the gestation-specific standard curve only if: (1) ferritin concentrations of individual infants were available; (2) gestational ages of the subjects were specified within 2 weeks, and (3) the data came from infants not at risk for abnormal fetal/neonatal iron metabolism (e.g., maternal iron deficiency, diabetes mellitus, IUGR, smoking and inflammatory conditions). The individual serum ferritin concentrations of the subjects and their respective gestational ages were analyzed to determine the mean and the 5th and 95th percentile confidence limits of the relationship of ferritin to gestational age. Additional articles that provided individual subject cord serum ferritin concentration grouped by either term or pre-term birth (but not specific gestational age) were included only to analyze the 5th, 25 th, 50th, 75th and 95th percentiles for the term ( $\geq 37$ weeks estimated gestational age) vs. pre-term ( $<37$ weeks estimated gestational age) infants. The data from these articles was not utilized for the gestation specific regression analysis.

\section{Analysis Based on Two Contemporary Data Sets}

In the contemporary data set, cord serum ferritin concentrations at birth at specific gestational ages were obtained from infants born between 23 and 41 weeks gestation enrolled in ongoing studies at the University of Minnesota and the University of Iowa [16]. Institutional Review Boards at both institutions approved the study, and informed consent was obtained from the mothers. Two groups of infants were enrolled. The low-risk control group consisted of infants born to mothers whose pregnancies were uncomplicated by conditions known to alter fetal/neonatal iron status, including anemia, diabetes mellitus, IUGR and smoking. The second group consisted of infants with one of three gestational risk factors for altered fetal/neonatal iron status: maternal diabetes mellitus, IUGR and maternal smoking [8, 46, 47]. Infants with more than one risk factor were excluded from analysis. Infants with umbilical cord serum ferritin values $>370 \mu \mathrm{g} / \mathrm{l}$ were excluded because such values were rarely found in the literature analysis and likely reflected infants with documented or undocumented inflammatory or iron-overloaded states. Infants with chromosomal anomalies, congenital syndromes or infections were also excluded from both groups. 
Fig. 1. Ferritin concentrations as a function of gestational age in infants from the combined control data sets. The regression line and its 5th and 95th percentile confidence limits for the mean regression are shown ( $\mathrm{n}=245, \mathrm{r}=0.30, \mathrm{r}^{2}=0.09, \mathrm{Y}=$ $6.01 X-74.56 ; \mathrm{p}<0.001)$.

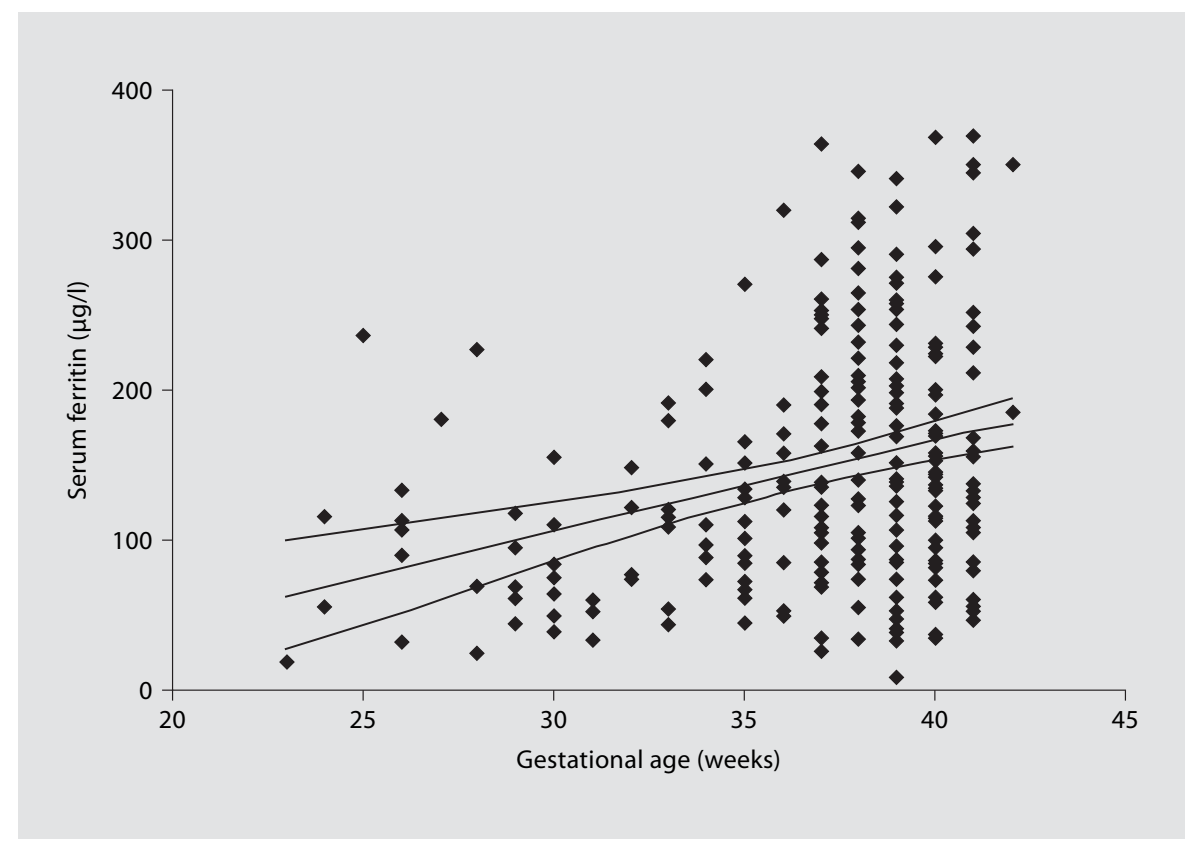

\section{Analytical Methods}

Serum ferritin was measured by chemiluminescent immunoassay (Beckman Access Immunoassay System; Beckman-Coulter Inc.; Brea, Calif., USA) at the University of Minnesota and by radioimmunoassay at the University of Iowa. Inter-assay variability was 5.2 and $6.9 \%$ for ferritin concentrations assayed at the two institutions, respectively. Studies included from the review of literature had used different assay techniques as well. Since various assay methods correlate well and inter-laboratory differences are similar to batch-to-batch variability within a laboratory $[22,68]$, no attempt was made to control for the methodology.

\section{Data Management and Statistical Analysis}

Linear regression analysis was used to assess the relationship between gestational age and serum ferritin concentration in the remainder of the infants from the historical data set and the low-risk control infants from the current enrollment. The a priori intention was to combine the data sets if no statistical difference existed between the two. The 95\% confidence interval of the slope and intercept for each curve was calculated. Given the relatively low number of subjects at gestational age $<30$ weeks, the relatively low trajectory of the slope for ferritin across gestational age and the pronounced tendency for the historical literature to group subjects into term and pre-term infants, we calculated the 5th, 25th, 50th, 75th and 95th centiles for term and pre-term control infants, instead of gestation-specific centiles.

To address our second objective, linear regression was used to compare the relationship between ferritin concentration and gestational age in each of the three risk groups. The slopes and intercepts of the regression lines for the three high-risk groups were compared with the low-risk control group. The fraction of the variation $\mathrm{r}^{2}$, shared between $\mathrm{X}$ and $\mathrm{Y}$, was analyzed for all the regression models. Statistical significance was set at a $\mathrm{p}$ value $<0.05$.

\section{Results}

We included 626 high- and low-risk newborn infants from 23 to 41 weeks gestation from the historic and contemporary data sets. After excluding 23 and 24 infants who met one of the exclusion criteria in the historical cohort and the contemporary cohort, respectively, we qualified 298 infants from the literature and 281 infants from the current data set for the final analysis. The excluded infants included 8 term infants with high serum ferritin concentrations $(>370 \mu \mathrm{g} / \mathrm{l})$ in the current data set and 4 term and 3 pre-term infants in the historic data set. Data from the literature consisted of a single study of 86 term and pre-term infants where gestation-specific cord serum ferritin concentrations were documented [29] and 
Fig. 2. The regression lines for infants of mothers who smoke $\left(\mathrm{n}=19, \mathrm{r}=0.44, \mathrm{r}^{2}=\right.$ $0.13, \mathrm{Y}=8.26 \mathrm{X}-194.02 ; \mathrm{p}=\mathrm{NS})$, infants of diabetic mothers (IDM, $\mathrm{n}=70, \mathrm{r}=0.22$, $\left.\mathrm{r}^{2}=0.05, \mathrm{Y}=5.65 \mathrm{X}-124.00 ; \mathrm{p}=\mathrm{NS}\right)$, and infants with IUGR $\left(\mathrm{n}=33, \mathrm{r}=0.42, \mathrm{r}^{2}=\right.$ $0.18, Y=9.43 X-195.67$; $p<0.01$ ) in comparison with the combined control group.

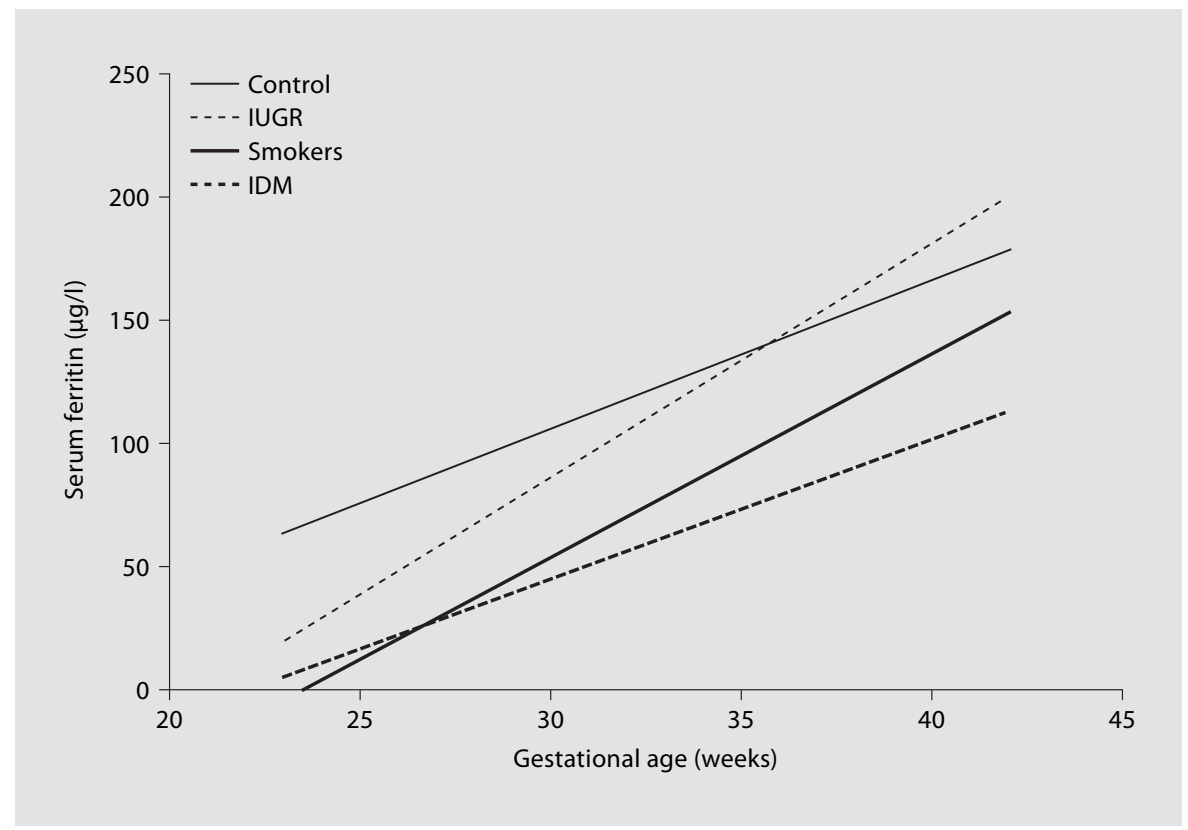

212 infants from five additional studies that provided specific cord serum ferritin concentration for individual subjects who were categorizable as either term or preterm infants $[19,20,31,34,42]$. The contemporary data set provided gestational age-specific cord serum ferritin concentrations for 159 low-risk control infants between 23 and 41 weeks, as well as 122 high-risk infants comprised of 70 IDM, 33 IUGR and 19 infants born to mothers who smoked during pregnancy.

The regression lines generated from the historical data set and the low-risk control infants from the contemporary data set were not statistically different and thus, the data sets were collapsed to generate a single standard curve (fig. 1). The prediction line and the $95 \%$ confidence intervals for the mean demonstrated that cord ferritin concentrations increased with advancing gestational age $(\mathrm{p}<0.001)$ from a mean of $63 \mu \mathrm{g} / \mathrm{l}$ at 23 weeks gestation to $171 \mu \mathrm{g} / \mathrm{l}$ at 41 weeks. The 95 th confidence band was wider for lower gestational infants in comparison with the term infants reflecting the fewer subjects at these gestational ages.

The calculated 5th, 25th, 50th, 75th and 95th centiles for term and pre-term control infants are shown in table 1. Ferritin concentrations were lower for the pre-term infants compared with term infants, although both groups had similar 5 th centile values: $<40 \mu \mathrm{g} / \mathrm{l}$ in term infants and $<35 \mu \mathrm{g} / \mathrm{l}$ in pre-term infants. Interestingly, $35 \mu \mathrm{g} / \mathrm{l}$ was the concentration predicted to be the level at
Table 1. Cord serum ferritin concentration percentiles for lowrisk term and pre-term infants

\begin{tabular}{lllllll}
\hline & \multicolumn{6}{c}{$\begin{array}{l}\text { Cord serum ferritin } \\
\text { concentration, } \mu \mathrm{g} / \mathrm{l}\end{array}$} \\
\cline { 2 - 7 } & Percentile: & 5 th & 25th & 50th & 75th & 95th \\
\hline Term $(\geq 37$ weeks $), \mathrm{n}=308$ & 40 & 84 & 134 & 200 & 309 \\
Pre-term (<37 weeks), $\mathrm{n}=149$ & 35 & 80 & 115 & 170 & 267 \\
\hline
\end{tabular}

which liver iron stores are low enough to compromise brain iron content, and below which newborn infants demonstrate abnormalities in recognition memory processing [13].

The three risk groups were compared with the control group using dummy coded variables for the intercept differences and slope differences using the standard practice [69]. The slopes of each of the 3 high-risk groups were not different from the control $\left[\Delta \mathrm{R}^{2}=0.003, \Delta \mathrm{F}(3,359)=\right.$ $0.422, \mathrm{p}=0.738]$ and were dropped from the equation. In contrast, significant differences were found for the intercept values $\left[\Delta R^{2}=0.092, \Delta F(3,362)=13.33, p<0.001\right]$. The IDM (fig. 2) group had a lower intercept than the control [-63.5 (10.44), $\mathrm{p}<0.001]$. 


\section{Discussion}

To date, the majority of studies had evinced the relationship between maternal and fetal iron status and the comparison of iron status between term and pre-term newborn infants. In merging data sets from the literature with data from two contemporary studies, we have been able to generate a standard curve for ferritin concentrations in newborns from 23 to 41 weeks and to define the 5th, 25th, 50th, 75th and 95th percentiles of ferritin concentrations for pre-term and term infants. These curves can be used to identify which infants are at neurodevelopmental risk from iron deficiency or iron overload during gestation.

The cross-sectional data may also be of use to guide postnatal iron therapy in term and pre-term infants. For example, term IDM, IUGR and infants of mothers who smoked during pregnancy and were born with low neonatal iron stores have significantly lower ferritin concentrations between 6 and 9 months of age [70,71], and thus enter their second postnatal year with a higher risk of becoming iron deficient [70]. The AAP currently recommends screening term infants for iron deficiency anemia between 9 and 12 months of age and high-risk infants including pre-term and low-birth-weight infants at an unspecified time point earlier than 9 months. There are no recommendations for IDM or infants of mothers who smoked during pregnancy either for screening or for early iron therapy [72]. High-risk term infants could be identified more specifically by using the 5 th centile cutoffs from the current study and they could be potentially screened earlier.

Pre-term infants have a highly variable iron status at the time of hospital discharge [73]. Factors that predispose pre-term infants to a net negative iron balance at 37 weeks post-conception include a low fetal endowment, excessive phlebotomy, late onset of iron supplementation, low levels of iron supplementation, recombinant human erythropoietin therapy and rapid postnatal growth. It is not unusual for pre-term infants to be discharged with $\mathrm{Hgb}$ concentrations as low as $75 \mathrm{~g} / \mathrm{l}$. If accompanied by low ferritin concentrations for post-conceptional age as defined by our standards, this would represent a significant reduction in total body iron [27]. Neutral iron balance is more likely in pre-term infants with older gestational ages at birth, early onset of enteral iron therapy, adequate iron supplementation and relatively slow postnatal growth. Finally, some pre-term infants have been documented with very high ferritin concentrations, indicative of iron overload $[74,75]$. Factors that may predis-
Table 2. Total body iron content of preterm infants*

\begin{tabular}{|c|c|c|c|c|c|}
\hline \multicolumn{2}{|c|}{ Serum ferritin concentration } & \multicolumn{4}{|c|}{ Hemoglobin concentration, g/l } \\
\hline$\mu \mathrm{g} / \mathrm{l}$ & Percentile & 75 & 100 & 120 & 140 \\
\hline 35 & 5 th & 65 & 79 & 90 & 101 \\
\hline 80 & 25 th & 81 & 94 & 105 & 116 \\
\hline 115 & 50 th & 88 & 101 & 112 & 123 \\
\hline 170 & 75 th & 95 & 109 & 120 & 131 \\
\hline 267 & 95th & 104 & 117 & 128 & 139 \\
\hline
\end{tabular}

* Total body iron content (TBI) was determined as follows: $\mathrm{TBI}=\mathrm{Hgb}$ iron content $(\mathrm{HbI})+$ body storage iron $(\mathrm{BSI})+$ functional iron in tissues. $\mathrm{HbI}=$ Body weight $(\mathrm{kg}) \times \mathrm{Hgb}(\mathrm{g} / \mathrm{dl}) \times$ 2.74 [76], BSI = $21.99 \log$ (serum ferritin) - 29.04 [76, 77]. Functional iron content in tissues $=7 \mathrm{mg} / \mathrm{kg}[27,28]$.

pose pre-term infants to iron overload include multiple RBC transfusions, early onset of intravenous iron therapy and potentially, extremely aggressive enteral iron therapy. The total body iron status of the discharged pre-term infant may vary by a factor of two, ranging from 65 to 140 mg (table 2).

The enteral iron requirements of the discharged preterm infant during the first year can be estimated from $\mathrm{Hgb}$ and ferritin concentrations at discharge. A pre-term infant discharged at approximately 37 weeks post-conception age with a weight of $2 \mathrm{~kg}$, who is expected to reach a weight of $10 \mathrm{~kg}$ at 12 months corrected age would require $3.5 \mathrm{mg}$ of elemental iron daily if the infant's iron endowment is adequate at discharge (serum ferritin $\geq 116$ $\mu \mathrm{g} / \mathrm{l})$ but would require $4.3 \mathrm{mg}$ daily if iron stores are low (serum ferritin $<35 \mu \mathrm{g} / \mathrm{l}$ ). This suggests that the current recommendation of the American Academy of Pediatrics to supplement $2 \mathrm{mg} / \mathrm{kg} /$ day of elemental iron for all exclusively breastfed premature infants during the first year of life [72], may be inadequate for the iron-deficient preterm infant. Future studies are required to determine the likely long-term impact of such supplementation.

It may be prudent to closely monitor the iron status of pre-term infants with low iron stores for development of postnatal iron deficiency while in the hospital. Currently there are no recommendations from the American Academy of Pediatrics or any other organization on monitoring of iron status, as well as adjusting the dose of iron supplementation in response to monitoring in pre-term infants. Depending upon the number of RBC transfusions, the serum ferritin concentration varies widely in these infants. As with other age groups, low 
ferritin is seen only in conditions of iron deficiency during the perinatal period. Therefore, infants identified with low ferritin concentrations for their post-conceptional age based on the data in the current study may benefit from either early institution of iron supplementation (e.g., from 2 weeks instead of from 1 month as currently recommended) or higher dose (e.g., $4 \mathrm{mg} / \mathrm{kg} /$ day instead of $2 \mathrm{mg} / \mathrm{kg} /$ day). On the other hand, it may be prudent to withhold iron supplementation or reduce the dose in pre-term infants with elevated serum ferritin concentrations for post-conceptional age ( $>90$ th percentile), since their total body iron status as well as the fate of the supplemented iron in these situations is unknown.

Finally, determining the serum ferritin for gestational age at discharge may also potentially be used as a starting point for monitoring the iron status of pre-term infants after discharge. Serum ferritin decreases during the first year of life [78]. In pre-term infants $<1,700 \mathrm{~g}$ a serum ferritin $<50 \mu \mathrm{g} / \mathrm{l}$ at 2 months portends the risk of subsequent early-onset iron deficiency [79]. Therefore, serum ferritin and Hgb could be measured at 2 months of postnatal age, and every 2 months thereafter until 6 months of age, i.e. during the period when the iron demand is likely to be higher due to rapid growth rate in pre-term infants. Those infants with birth weight $<1,500 \mathrm{~g}$, those consuming breast milk exclusively or low iron formula or cow's milk, and those who had received few RBC transfusions during the neonatal period and in whom iron supplementation was delayed are likely to benefit the most from such screening.

Beyond 6 months of age, serum ferritin does not correlate well with measures of erythropoiesis in pre-term infants [78]. Therefore, serum ferritin may not be a reliable indicator of iron deficiency as a stand-alone lab test. Additional tests of iron deficiency, such as Hgb, mean corpuscular volume, red cell distribution width, $\mathrm{ZnPP} / \mathrm{H}$ ratio and transferrin saturation are necessary to monitor total body iron status at this age.

\section{Conclusion}

We have reviewed the importance of assessing neonatal iron status in the term and pre-term infant. The normative curve of cord serum ferritin concentration may be useful for identifying infants with iron deficiency at birth and thus, at risk of long-term neurodevelopmental impairments. Infants with serum ferritin in the lower quartile may benefit from close monitoring of their iron status. One weakness of the study is relatively few subjects ( $10 \%$ of total) with gestational ages $\leq 30$ weeks. Additional studies are needed to validate the normative ferritin values at lower gestational ages and to evaluate the usefulness of the normative curve for determining the optimal dosage of iron supplementation. Future studies are also needed to compare the usefulness of serum ferritin vis-à-vis other biomarkers of iron status at birth and beyond.

\section{Acknowledgements}

This work was supported in part by a grant from the National Institutes of Health (HD29421) to M.K.G. The editorial assistance of Ann Fandrey and Eric Reese is gratefully acknowledged.

\section{References}

1 Dallman PR: Biochemical basis for the manifestations of iron deficiency. Ann Rev Nutr 1986;6:13-40.

2 Youdim MBH, Yehuda S: The neurochemical basis of cognitive deficits induced by brain iron deficiency: involvement of dopamine-opiate system. Cell Mol Biol 2000;46: 491-500.

3 Connor JR, Menzies SL: Altered cellular distribution of iron in the central nervous system of myelin deficient rats. Neuroscience 1990;34:265-271.

-4 Yu GSM, Steinkirchner TM, Rao GA, Larkin EC: Effect of prenatal iron deficiency on myelination in rat pups. Am J Pathol 1986;125: $620-624$.
5 deUngria M, Rao R, Wobken JD, Luciana M, Georgieff MK: Perinatal iron deficiency decreases cytochrome c oxidase activity in selective regions of the brain. Pediatr Res 2000; 48:169-176.

-6 Petry CD, Eaton MA, Mills MM, Johnson $\mathrm{DE}$, Georgieff MK: Iron deficiency of liver, heart, and brain in newborn infants of diabetic mothers. J Pediatr 1992;121:109-114.

7 Georgieff MK, Landon MB, Mills MM, Hedlund BE, Faassen AE, Schmidt RL, Ophoven JJ, Widness JA: Abnormal iron distribution in infants of diabetic mothers: spectrum and maternal antecedents. J Pediatr 1990;117: 455-461.
8 Chockalingam UM, Murphy E, Ophoven JC, Weisdorf SA, Georgieff MK: Cord transferrin and ferritin values in newborn infants at risk for prenatal uteroplacental insufficiency and chronic hypoxia. J Pediatr 1987;111:283286.

-9 Lozoff B, Jimenez E, Hagen J, Mollen E, Wolf AW: Poorer behavioral and developmental outcome more than 10 years after treatment for iron deficiency in infancy. Pediatrics 2000; 105:e51

10 Grantham-McGregor S, Ani C: A review of studies on the effect of iron deficiency on cognitive development in children. J Nutr 2001;131:649S-668S. 
11 Fleming RE: Cord serum ferritin levels, fetal iron status, and neurodevelopmental outcomes: correlations and confounding variables. J Pediatr 2002;140:145-148.

-12 Tamura T, Goldenberg R, Hou J, Johnston K, Cliver SP, Ramsey SL, Nelson K: Cord serum ferritin concentrations and mental and psychomotor development of children at five years of age. J Pediatr 2002;140:165-170.

-13 Siddappa AM, Georgieff MK, Wewerka S, Worwa C, Nelson CA, deRegnier R-A: Auditory recognition memory in iron-deficient infants of diabetic mothers. Pediatr Res 2004;55:1034-1041.

-14 Armony-Sivan R, Eidelman AI, Lanir A, Sredni D, Yehuda S: Iron status and neurobehavioral development of premature infants. J Perinatol 2004;24:757-762.

-15 Beard J, deRegnier RA, Shaw M, Rao R, Georgieff M: Diagnosis of iron deficiency in infancy. Lab Med 2007;38:103-108.

$\checkmark 16$ Lott DG, Zimmerman MB, Labbe RF, Kling PJ, et al: Erythrocyte zinc protoporphyrin is elevated with prematurity and fetal hypoxemia. Pediatrics 2005;116:414-422.

$\checkmark 17$ Juul.SE, Zerzan JC, Strandiord TP, Woodrum DE: Zinc protoporphyrin/heme as an indicator of iron status in nicu patients. J Pediatr 2003;142:273-278.

-18 Siimes MA, Addiego JE, Dallman PR: Ferritin in serum: diagnosis of iron deficiency and iron overload in infants and children. Blood 1974;43:581-590.

19 Rios E, Lipschitz DA, Cook JD, Smith NJ: Relationship of maternal and infant iron stores as assessed by determination of plasma ferritin. Pediatrics 1975;55:694.

-20 Lipschitz DA, Cook JD, Finch CA: A clinical evaluation of serum ferritin as an index of iron stores. N Engl J Med 1974;290:12131216.

-21 Walters GO, Miller FM, Worwood M: Serum ferritin concentration and iron stores in normal subjects. J Clin Pathol 1973;26:770772 .

-22 Cook JD: Clinical evaluation of iron deficiency. Semin Hematol 1982;19:6-18.

-23 MacPhail AP, Charlton RW, Bothwell TH, Torrance JD: The relationship between maternal and infant iron status. Scand J Hematol 1980;25:141-150.

-24 Baynes RD: Assessment of iron status. Clin Chem 1996;29:209-215.

-25 Cook JD, Skikne BS: Iron deficiency: definition and diagnosis. J Intern Med 1989;226: 349-355.

26 Bothwell TH: Iron requirements during pregnancy and strategies to meet them. Am J Clin Nutr 2000;72:257S-264S.

-27 Oski FA: Iron deficiency in infancy and childhood. New Engl J Med 1993;329:190193.

28 Widdowsen EM, Sray CM: Chemical development in utero. Arch Dis Child 1951;26: 205-214.
29 Siimes ASI, Siimes MA: Changes in the concentration of ferritin in the serum during fetal life in singletons and twins. Early Hum Dev 1986;13:47-52.

30 Messer RD, Russo AM, McWhirter WR, Spragemeyer D, Halliday JW: Serum ferritin in term and preterm infants. Aust Paediatr J 1980;16:185-188.

31 Jansson L, Holmberg L, Ekman R: Variation of serum ferritin in low birth weight infants with maternal ferritin, birth weight and gestational age. Acta Haematol 1979;62:273277.

32 Sweet DG, Tubman TRJ, Lappin TRJ, Halliday HL: Study of maternal influences on fetal iron status at term using cord blood transferrin receptors. Arch Dis Child Fetal Neonatal Ed 2001;84:F40-F43.

33 Carpani G, Marini F, Buscaglia M, Sinigaglia E, Moroni G: Red cell and plasma ferritin in normal fetuses at different ages of gestation. Eur J Haematol 1992;49:260-262.

34 Haga P: Plasma ferritin concentrations in preterm infants in cord blood and during the early anemia of prematurity. Acta Pediatr Scand 1980;69:637-641.

35 Hussain MAM, Gaafar TH, Laulight M, Hoffbrand AV: Relation of maternal and cord blood ferritin. Arch Dis Child 1977;52: 782-784.

36 Lao TT, Loong EPL, Chin RKH, Lam CWK, Lam YM: Relationship between newborn and maternal iron status and hematological indices. Biol Neonate 1991;60:303-307.

37 Kelly AM, MacDonald DJ, Mc Dougall AN: Observations on maternal and fetal ferritin concentrations at term. Br J Obstet Gynaecol 1978;85:338-343.

38 Agarwal RMD, Tripathi AM, Agarwal KN: Cord blood hemoglobin, iron and ferritin status in maternal anemia. Acta Paediatr Scand 1983;72:545-548.

39 Erdem A, Erdem M, Arslan M, Yazici G, Eskandari R, Himmetoglu O: The effect of maternal anemia and iron deficiency on fetal erythropoiesis: comparison between serum erythropoietin, hemoglobin and ferritin levels in mothers and newborns. J Matern Fetal Neonatal Med 2002;11:329-332.

40 Ziaei S, Hatefnia E, Togeh GH: Iron status in newborns born to iron-deficient mothers. Iran J Med Sci 2002;28:62-64.

41 Puolakka J, Janne O, Vihko R: Evaluation by serum ferritin assay of the influence of maternal iron stores on the iron status of newborns and infants. Acta Obstet Gynecol Scand Suppl 1980;95:53-56.

42 Ilyes I, Jezerniczky J, Kovacs J, Dvoracsek E, Csorba S: Relationship of maternal and newborn serum ferritin concentrations measured by immunoradiometry. Acta Paediatr Hung 1985;26:317-321.

43 Fenton V, Cavill I, Fisher J: Iron stores in pregnancy. Br J Haematol 1977;37:145-149.
44 O’Brien KO, Zavaleta N, Abrams SA, Caufield LE: Maternal iron status influences iron transfer to the fetus during the third trimester of pregnancy. Am J Clin Nutr 2003;77: 924-930.

45 Georgieff MK, Petry CD, Wobken JD: Liver and brain iron deficiency in newborn infants with bilateral renal agenesis (Potter's syndrome). Pediatr Pathol Lab Med 1996;16: 509-519.

46 Georgieff MK, Landon MB, Mills MM, Hedlund BE, Faassen AE, Schmidt RL, Ophoven JJ, Widness JA: Abnormal iron distribution in infants of diabetic mothers: spectrum and maternal antecedents. J Pediatr 1990;117: 455-461.

47 Sweet DG, Savage GA, Tubman R, Lappin TRJ, Halliday HL: Cord blood transferrin receptors to assess fetal iron status. Arch Dis Child Fetal Neonatal Ed 2001;85:F46-F48.

48 Georgieff MK, Widness JA, Mills MM, Stonestreet BS: The effect of prolonged intrauterine hyperinsulinemia on iron utilization in fetal sheep. Pediatr Res 1989;26:467-469.

49 Widness JA, Susa JB, Garcia JF, Singer DB, Seghal P, Oh W, Schwartz R, Schwartz HC: Increased erythropoiesis and elevated erythropoietin in infants born to diabetic mothers and in hyperinsulinemic rhesus fetuses. J Clin Invest 1981;67:637-642.

50 Murata K, Toyoda N, Ichio T, Ida M, Sugiyama $\mathrm{Y}$ : Cord transferrin and ferritin values for erythropoiesis in newborn infants of diabetic mothers. Endocrinol Jpn 1989;36:827832.

51 Philipps AF, Porte PJ, Strabinsky S, Rosenkranz TS, Raye JR: Effects of chronic fetal hyperglycemia upon oxygen consumption in the ovine uterus and conceptus. J Clin Invest 1984;74:279-286.

52 Milley JR, Papacostas JS, Tabata BK: Effect of insulin on uptake of metabolic substrates by the sheep fetus. Am J Physiol 1986;251: E349-E56.

53 Georgieff MK, Petry CD, Mills MM, McKay $\mathrm{H}$, Wobken JD: Increased $\mathrm{N}$-glycosylation and reduced transferrin-binding capacity of transferrin receptor isolated from placentae of diabetic women. Placenta 1997;18:563568 .

54 Meberg A, Haga P, Sande H, Foss OP: Smoking during pregnancy - hematological observations in the newborn. Acta Pediatric Scand 1979;68:731-734.

55 Gruslin A, Perkins SL, Manchanda R, Fleming N, Clinch JJ: Maternal smoking and fetal erythropoietin. Obstet Gynecol 2000;95: 561-564.

56 Morton RE, Nysenbaum A, Price K: Iron status in the first year of life. J Pediatr Gastroenterol Nutr 1998;1:707-712.

57 Halliday HL, Lappin TRJ, McClure G: Iron status of the preterm infant during the first year of life. Biol Neonate 1984;45:228-235.

58 Emery D, Barry D: Comparison of Maori and non-Maori maternal and fetal iron parameters. N Z Med J 2004;117:909-913. 
59 Zavaleta N, Caulfield LE, Garcia T: Changes in iron status during pregnancy in Peruvian women receiving prenatal iron and folic acid supplements with or without zinc. Am J Clin Nutr 2000;71:956-961.

-60 Celada A, Busset R, Gutierrez J, Herreros V: Maternal and cord blood ferritin. Helv Paediatr Acta 1982;37:239-244.

-61 Nemet K, Andrassy K, Bognar K, Czappan P, Stuber A, Simonovits I: Relationship between maternal and infant iron stores. 1. Fullterm infants. Haematologia (Budap) 1986;19:197-205.

-62 Milman N, Agger AO, Nielsen OJ: Iron status markers and serum erythropoietin in 120 mothers and newborn infants. Acta Obstet Gynecol Scand 1994;73:200-204.

-63 Gaspar MJ, Ortega MR, Moreiras O: Relationship between iron status in pregnant women and their newborn babies. Acta Obstet Gynecol Scand 1993;72:534-537.

-64 Wallenburg HCS, Van Eijk: Effect of oral iron supplementation during pregnancy on maternal and fetal iron status. J Perinat Med 1984;12:7-12.

-65 Singla PN, Tyagi M, Shankar R, Dash D, Kumar A: Fetal iron status in maternal anemia. Acta Pediatr 1996;85:1327-1330.

-66 Kurtoglu S, Atabek ME, Gunes T, Akcakus M, Keskin M, Kocaoglu C: Relationship between cord blood levels of IGF-I and ferritin in healthy term neonates. J Pediatr Endocrinol Metab 2004;17:737-742.
67 Tamura T, Hou J, Goldenberg RL, Johnston KE, Cliver SP: Gender difference in cord serum ferritin concentrations. Biol Neonate 1999;75:343-349.

-68 Stacy DL, Han P: Serum ferritin measurements and the degree of agreement using four techniques. Am J Clin Pathol 1992;98: 511-515.

69 Cohen J, Cohen P, West SG, Aiken LS: Applied Multiple Regression/Correlation Analysis for the Behavioral Sciences, ed 3. Mahwah, Erlbaum, 2003, pp 303-320.

70 Georgieff MK, Wewerka SW, Nelson CA, deRegnier R-A: Iron status at 9 months of infants with low iron stores at birth. J Pediatr 2002;141:405-409.

71 Kilbride J, Baker TG, Parapia LA, et al: Anaemia during pregnancy as a risk factor for iron-deficiency anaemia in infancy: a casecontrol study in Jordan. Int J Epidemiol 1999;28:461-468.

72 American Academy of Pediatrics Committee on Nutrition: Nutritional needs of the preterm infants; in Kleinman RE (ed): Pediatric Nutrition Handbook, ed 5. Chapel Hill, NC American Academy of Pediatrics, 2004, pp 23-54.
73 Georgieff MK: Iron; in Hay WH Jr, Thureen P (eds): Neonatal Nutrition and Metabolism, ed 2. Cambridge, Cambridge University Press, 2006, pp 291-298.

74 Cooke RW, Drury JA, Yoxall CW, James C: Blood transfusion and chronic lung disease in preterm infants. Eur J Pediatr 1997;156: 47-50.

75 Inder TE, Clemett RS, Austin NC, Graham P, Darlow BA: High iron status in very low birth weight infants is associated with an increased risk of retinopathy of prematurity. J Pediatr 1997;131:541-544.

76 Saarinen UM, Siimes MA: Iron absorption from breast milk, Cow's milk and iron- supplemented formula: an opportunistic use of changes in total body iron determined by hemoglobin, ferritin and body weight in 132 infants. Pediatr Res 1979;13:143-147.

77 Calvo EB, Galindo AC, Aspres NB: Iron status in exclusively breast fed infants. Pediatrics 1992;90:375-379.

78 Griffin IJ, Reid MM, McCormick KP, Cooke RJ: Zinc protoporphyrin/haem ratio and plasma ferritin in preterm infants. Arch Dis Child Fetal Neonatal Ed 2002;87:F49-F51.

79 Lundstrom U, Siimes MA, Dallman PR: At what age does iron supplementation become necessary in low-birth-weight infants? J Pediatr 1977;91:878-883. 